\title{
ナイロン66フィルムの延伸，熱処理過程 における無定形領域の微細構造変化
}

\begin{tabular}{|c|c|c|c|c|c|}
\hline \multirow[t]{3}{*}{ 旭化成工業 } & 緎維加工研究所 & 上 & 出 & 健 & 二（会員） \\
\hline & "I & 真 & 鍋 & 征 & 一（会員） \\
\hline & "I & 原 & & 正 & 勝 \\
\hline & " & 中 & 山 & 暢 & 三 \\
\hline
\end{tabular}

\section{Change in Fine Structure in Amorphous Region of Nylon 66 Film with Stretching and Annealing.}

Kenji Kamide, Sei-ichi Manabe, Masakatsu Hara, Chozo Nakayama, Textile Research Laboratory, Asahi Chemical Industry Co., Ltd. Hacchonawate 11-7, Takatsuki-shi, Osaka.

\begin{abstract}
By using the method proposed in the previous papers, the detailed fine structure in amorphous region of nylon 66 film and filament is disclosed from their dynamic loss tangent $(\tan \delta$ )-temperature $(T)$ curve. In annealing process, the elastic modulus fraction $f_{e}$ decreases and heterogeneity index of amorphous region $n_{t}$ increases monotonously with an increase in annealing temperature $T_{a}$ for the unoriented film. In the annealing process of wet state, the $f_{e}$ related to $\alpha_{2}$ absorption, observed at $30^{\circ} \mathrm{C}$ (for $110 \mathrm{~Hz}$ ), decreases more abruptly than that of $\alpha_{1}$ absorption observed at $120^{\circ} \mathrm{C}$ (for $110 \mathrm{~Hz}$ ). On the contrary, in the annealing process of dry state, the $f_{e}$ related to $\alpha_{1}$ decreases more abruptly than $\alpha_{2}$. With an increase in stretching ratio, the $f_{0}$ of the stretched film and filament decrease and their $n_{t}$ increase monotonously. These tendencies of $f_{s}$ and $n_{t}$ during annealing and stretching are not limited to nylon 66, but have a general characters for another fiber-forming polymers, such as polyacrylonitrile, polyethyleneterephthalate, polypropylene and polyvinylalcohol.

Both $f_{e}$ and $n_{t}-T_{a}$ curves of the stretched film show minimum when the film is annealed in dry state for a fixed time of period and $n_{t}$ increases nonotonously with $T_{a}$ when the film is annealed in wet state. The complicated $T_{a}$ dependence of $f_{b}$ and $n_{t}$ can be explained in terms of disorientation of oriented polymeric chains in the annealing process.

A new peak in $\tan \delta-T$ curve is observed at ca. $90^{\circ} \mathrm{C}$ (for $110 \mathrm{~Hz}$ ) for the samples annealed in dry state at $T_{a}=200^{\circ} \mathrm{C}$. This peak is closely connected to the amorphous state produced during the annealing process. Several peaks are observed in the main dispersion region of $\tan \delta-T$ curve, corresponding to the annealing in dry or wet state and adsorption of water and these can reasonably be resolved by the theory in the view of heterogenieties of the packing states of polymeric chains in amorphous region.

(Received August 9, 1977)

\section{摘要}

目 的 熱処理, 延伸, 延伸後熱処理に伴う微細構造の変化を, 力学的損失正接-温度曲線（ $\tan \delta-T$ 曲線）を用いて明らかに する.

方 法 無配向フィルム扰よび延伸フィルムを種々の熱処理温度 $T_{a}$, 熱処理時間 $t_{a}$ で自由端熱処理する（湿熱処理条件; $T_{a}$
\end{abstract}


$=40 \sim 140^{\circ} \mathrm{C}, t_{a}=5 \sim 120 \mathrm{~min}$, 乾熱処理条件; $T_{a}=50 \sim 220^{\circ} \mathrm{C}, t_{a}=5 \sim 60 \mathrm{~min}$ ). 上記フィルム招よび䋐維の $\tan \delta-T$ 时線を測定 し，著者らの解析法をこの曲線に適用して無定形領域内部の微細構造を定量的に評俩する.

結 果 (1) 無配向フィルムを熱処理する際, $T_{a}$ が上昇すると $120^{\circ} \mathrm{C}(110 \mathrm{~Hz})$ 付近の吸収 ( $\alpha_{1}$ 吸収), $30^{\circ} \mathrm{C}$ 付近の吸収 ( $\alpha_{2}$ 吸収) の弾性率分率 $f_{e}$ は減少し, 不均一度指数 $n_{t}$ は増加する. 湿熱処理では $a_{2}$ 吸収の $f_{e}$ が, 乾熱处理では $a_{1}$ 吸収の $f_{e}$ が顕著に減少する.これらの変化は熱処理の初期に抢いて著しい.（2） $T_{a}=200^{\circ} \mathrm{C}$ の乾熱処理で $\alpha_{2}{ }^{\prime}$ 吸収（水分率 $0 \%$ の時, $90^{\circ} \mathrm{C}$ 付近に存在する吸収）が出現する. 湿熱処理では $\alpha_{1}$ 吸収が $\alpha_{2}^{\prime}$ 吸収にくらぺて相対的に大きくなる.（3）延伸に伴いフィルム 扣よび織維の無定形領域内部の分子鎖の充媜状態はより密になり，その充填状態の不均一さは堌大する. (4) $T_{a}$ を変動させて延 伸フィルムを乾熱処理すると $T_{a}=160^{\circ} \mathrm{Cで} f_{e}, n_{t}$ は最小值を示し, 湿熱処理すると $n_{t}$ は $T_{a}$ とともに単調に増加し, $T_{a}=120^{\circ} \mathrm{C}$ で $\alpha_{2}$ 吸収の $f_{e}$ のみが極大值を示す.

(昭和52年 8 月 9 日受理)

\section{1. 緒 言}

繊維の無定形領域の微細構造は染色性・吸湿性之密接 に関係している.乙の微細構造を定量的に評価するてと は実用上からあ重要である。既報 (4) に打いて著者らは 分子鎖の充填度分布関数 $F(n)$ の概念を新しく導入し, てれを利用して繊維を含めた結晶性高分子の無定形領域 の微細構造を定量的に 表現する方法を提案した。なお $F(n)$ は力学的損失正接 $(\tan \delta)$ 一温度 $(T)$ 曲線, およ び見掛けの活性化エネルギ $\Delta H_{a}$ の両者の実測值より 定められる．乙の方法をポリアクリロニトリル（PAN） 汇適用し，その無定形領域の微細構造分布を染色性や延 伸, 熱処理過程と関連させて明らかにした5 .7)。またナ イロン66(N66)仮撚加工前の繊維（原糸）の無定形領域 内部の分子鎖の充填状態の不均一さを不均一度指数 $n_{t}$ で評価した ${ }^{8)}$ 。その結果, N66 原系の $n_{t}$ (約3.3) は製 杀条件によって変動するがアクリル繊維原条 $\left(n_{t} \doteqdot 2.5\right)$, ポリエステル緘維原糸 $\left(n_{t} \fallingdotseq 3.0\right)$ に比べて大きい.

N66 の分子鎖間には van der Waals 結合のほかに アミド基間に働く水素結合が混在する，乙のために，分 子鎖の充填状態の不均一さ, 従って $n_{t}$ が大きくなると 解釈できる. 水素結合密度の高い領域では分子鎖は密に 充填し, van der Waals 結合のみの領域では分子鎖は 比較的粗に充填する.

本研究では, (1)無配向フィルムの熱処理, 延伸およ び延伸・熱処理に伴う微細構造の変化，および(2)延伸 フィルムと瀻維の微細構造の差を, 主として $\tan \delta-T$ 曲線を利用して明らかにする。

\section{2. 理 論}

緩和時間 $\tau$ の温度依存性がアレニウス式で近似される とき（ $\Delta H_{a}$ が温度に依存せず一定のとき）の $\tan \delta-T$ 曲線の解析理論 ${ }^{4)}$ を示す.

図 1 亿実測の $\tan \delta-T$ 曲線の典型的な 3 種の形を示 す. 図1(a)には 1 個の $\tan \delta$ のピークを中心に厇い 温度範囲で $\tan \delta-T$ 曲線が実測されている場合を示す。 $T_{1}, T_{2}$ は, $\tan \delta-T$ 曲線を図中破線のように外插した ときのそれぞれ低温側および高温側で $\tan \delta=0$ となる 温度 $(\mathrm{K})$ である. $T_{\max }$ はピーク温度 $(\mathrm{K}),(\tan \delta)_{\max }$ は ピーク值, $\Delta T_{1 / 2}$ は $\tan \delta-T$ 曲線の半価幅である. 図

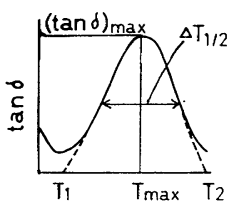

(a)

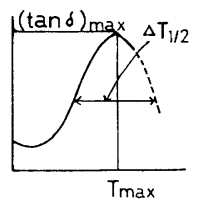

温度

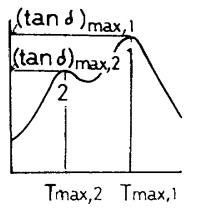

(c)
図 $1 \tan \delta-T$ 曲線の実測例でみられる典型的な 3 種の形 : (a)； 1 個の $\tan \delta$ のピークを中心に広い温度範囲で測定さ れている $\tan \delta-T$ 曲線，(b); $T_{\max }$ あるいは $T_{\max }$ よりわ ずか高温まで測定されている $\tan \delta-T$ 曲線，(c)： $\Lambda H_{a}$ の異 なる 2 種の吸収（吸収 1 扰よび吸収 2 ）の $T_{\max }$ の差が小さ いときの $\tan \delta-T$ 曲線. 図中破線はデー夕の外捙線を意味す る. $T_{1}, T_{2}$ は $\tan \delta=0$ となるときの温度 $(\mathrm{K})$ (外插值), $(\operatorname{tam} \delta)_{\max } ; \tan \delta$ のピーク值, $T_{\max } ;$ ピーク温度 $(\mathrm{K}), \Delta T_{1 / 2}$ $; \tan \delta-T$ 曲線の半価幅 $(\mathrm{K})$, 添字 1,2 は吸収 1 , 吸収 2 を それぞれ意味する.

1 (b)には 1 個のピークについて $T_{\max }$, あるいは $T_{\max }$ よりわずかに高温まで実測されている場合を示す. 図 1 (c)には $\Delta H_{a}$ が相互に異なる2種の吸収（吸収1およ び吸収 2 )の $T_{\max }\left(T_{\max , 1}\right.$ および $\left.T_{\operatorname{maax}, 2}\right)$ の差が小さ く両吸収が混在する場合を示す. $(\tan \delta)_{\max , 1}$ および $(\tan \delta)_{\max , 2}$ はそれぞれ吸收 1 と 2 の $(\tan \boldsymbol{o})_{\max }$ であ る.図1の各場合の解析理論を以下にまとめて示す.な お解析理論の詳細は別報 ${ }^{4)}$ に示された。

2.11 個のピークを含む広い範囲の $\tan \delta-T$ 曲線が 測定可能な場合（図1 (a)の場合)

てがアレニウス式で与えられるとと，およびある注目 する微小要素) の $T_{\max }$ (すなわち $T_{\text {max }}{ }^{\prime}$ ) は $\tan \delta-T$ 曲線上では $T$ に相当するととを考慮すれば，分子鎖の充 填度 $n$ はその定義より(1)式で与えられる.

$$
n=\left(T-T_{\max }\right) T_{\max } /\left(\Delta T_{1 / 2}\right)_{R, m} \cdot T
$$

こてで, $\left(\Delta T_{1 / 2}\right)_{R, m}$ は $T_{\max }{ }^{\prime}=T_{\max }$ の要素の $\left(\Delta T_{1 / 2}\right)$ $R,\left(\Delta T_{1 / 2}\right)_{R}$ は Rouse 理論を適用して計算される $\tan$ $\delta-T$ 曲線の半価幅である. $F(n)$ はその定義より $(2)$ 式 で示される.

$$
\begin{aligned}
& F(n)=\left(T^{2} / T_{\max }\right)\left(1 /(\tan \delta)_{\max , R}\right)\{\tan \delta / T \\
& +T \int_{T_{1}}^{T}\left(\tan \delta / T^{3}\right) d T+\left[T\left(\ln T_{1}-\ln T\right) /\right. \\
& \left.\left.\left(\ln T_{2}-\ln T_{1}\right)\right] \int_{T_{1}}^{T_{2}}\left(\tan \delta / T^{3}\right) d T\right\} \ldots \ldots \ldots \ldots . .
\end{aligned}
$$

一方 (3)式が近似的に成立する.

$\left(\Delta T_{1 / 2}\right)_{R, m} / \Delta T_{1 / 2(S)}=(5 / 3)(\tan \delta)_{\max , R}+1.5$ 
$F(n)$ の規格条件および (3)式から，(4)式が導出され る.

$(\tan \delta)_{\max , R}=\left(-9+\sqrt{81+240 A_{2}}\right) / 20$

ここで, $A_{2}=\left(T_{\max } / \Delta T_{1 / 2(S)}\right) \int_{T_{1}}^{T_{2}}\{\tan \delta / T+$

$T \int_{T_{1}}^{T}\left(\tan \delta / T^{3}\right) d T+\left[T\left(\ln T_{1}-\ln T\right) /\left(\ln T_{2}\right.\right.$

$\left.\left.\left.-\ln T_{1}\right)\right] \int_{T_{1}}^{T_{2}}\left(\tan \delta / T^{3}\right) d T\right\} d T$

$\Delta T_{1 / 2(S)}=5.24 \times 10^{-3} T_{\max ^{2}} / \Delta H_{a}$

弾性率分率 $f_{e}$ は $(7)$ 式で与えられる。

$f_{e}=74.4(\tan \delta)_{\max , R} /\left\{\left[9.07 /\left((\tan \delta)_{\max , R}\right.\right.\right.$

$+0.244)-7.37]+74.4(\tan \delta)_{\max , R\}}$

$n t$ はその定義より(8)式で与えられる.

$n_{t}=(\tan \delta)_{\max , R} /(\tan \delta)_{\max }$

まず $T_{\max }$ と $\Delta H_{a}$ の実測值を(6)式に代入して $\Delta T$ 1/2(S) を計算する. $\Delta T_{1 / 2(S)}, T_{\max }$, および $\tan \delta-T$ 曲 線の值を(5)式に代入して算出した $A_{2}$ を(4)式に代入 して $(\tan \delta)_{\max , R}$ を計算する. $(\tan \delta)_{\max , R}$ を(7), (8)式に代入すれば $f_{e}, n_{t}$ が算出される. (6) 式の $\Delta T_{1 / 2(S)}$ 之 $(\tan \delta)_{\max , R}$ とを(3)式に代入して $\left(\Delta T_{1 / 2}\right)$ ${ }_{R, m}$ を定める. 乙の $\left(\Delta T_{1 / 2}\right)_{R, m}$ と $T_{\max }$ の值を(1) 式 飞代入すると， $n$ と $T$ との関係式が定まる.

いまTをある值に設定すれば，乙のTに対応する $n$ は (1) 式で計算される. (2)式に $T$ の設定值, $(\tan \delta)_{\max }$, ${ }_{R}, T_{\max }, T_{2}, T_{1}$, および $\tan \delta-T$ 曲線の実測值を代 入して, $F(n)$ が計算される.

$2.2 T_{\max }$ より高温側の $\tan \delta$ が測定不能な場合（図 1 ( b )の場合)

動的弾性率 $E^{\prime}$ が $T_{\max }$ より高温で著しく小さくなる ときには， $T_{\text {max }}$ より高温側の $\tan \delta$ の測定が困難な場 合が多い.また $T_{\max }$ より高温になると熱分解が起った りあるいは微細構造が著しく変化するときなどは，こ の例に当てはまる.

$\tan \delta-T$ 曲線より $T_{\max },(\tan \delta)_{\max }, \Delta T_{1 / 2}$ を読み 取る. 実測の $\Delta H_{a}$ と $T_{\text {max }}$ を(6)式代代大して $\Delta T_{1 / 2}(S)$ を算出する. $\Delta T_{1 / 2(S),}(\tan \delta)_{\max }, \Delta T_{1 / 2}$ を(9)式に代 入して $A_{2}$ を求める.

$A_{2} \fallingdotseq(\tan \delta)_{\max } \Delta T_{1 / 2} / \Delta T_{1 / 2(S)}$

$A_{2}$ を(4)式に代入して算出した $(\tan \delta)_{\max , R}$ を( 7 )お よび(8)式に代入してそれぞれ $f_{s}$ と $n_{t}$ を求める. 既 報4)で示したように $f_{e}$ は注目する吸収に寄与する領域 量の弾性率分率に等しい. $n_{t}$ は無定形領域内部の分子 鎖の充填状態の不均一度の目安であり $F(n)$ の半価幅 に近似的に等しいととが実験的に確かめられている（た だし厳密には $F(n)$ の分布の幅（例えば標準偏差）が 不均一度の目安である).

$2.3 \Delta H_{a}$ が相互に異なる 2 個の吸収の $T_{\max }$ の差が 小さい場合（図1 ( c )の場合)

この場合には $F(n)$ を撖密には定められない。 そと

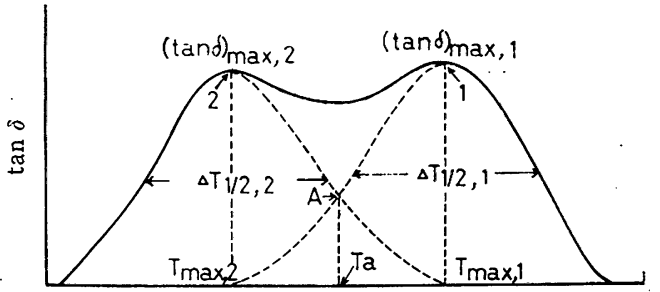

温度

図 2 図 1 (c)の場合の $\tan \delta-T$ 曲線の分割法を示す模式図 : $T_{a}$ は $\left(T_{a}-T_{\max , 2}\right) /\left(T_{\max , 1}-T_{a}\right)=(\tan \delta)_{\max , 2} /(\tan \delta)_{\max , 1}$ を満足する温度, 点 $\mathrm{A}$ は座標 $\left(T_{a}, \tan \delta / 2\right)$. の点

でそれぞれの吸収の $f_{e}$ と $n_{t}$ とを評価する。既報(1で 示した $\tan \delta-T$ 曲線の分割の模式図を図 2 亿示す. 高 温側の吸収 ( $\alpha_{1}$ 吸収) および低温側の吸収 ( $\alpha_{2}$ 吸収) の $(\tan \delta)_{\max }$ としては実測のピーク值 (図中点 1 および 2 の $\tan \delta$ 值), $(\tan \delta)_{\max , 1}$ と( $(\tan \delta)_{\max , 2}$ をそれぞ れ採用する. それぞれの吸収のピーク温度を $T_{\max , 1}$, $T_{\max , 2}$ として, $\left(T_{a}-T_{\max , 2}\right) /\left(T_{\max , 1}-T_{a}\right)=(\tan \delta)$ $\max , 2 /(\tan \delta)_{\max , 1}$ を満足する温度 $T_{a}$ を定める. $T_{a}$ に おりる $\tan \delta$ の $1 / 2$ の值の点 $\left(T_{a}, \tan \delta / 2\right)$, すなわち 図中 $A$ 点を定める. 点 $1, A$ および $T_{\text {max }, 2}$ を通る滑らか

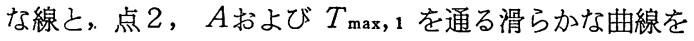
描き，半価幅 $\Delta T_{1 / 2,1}$ と $\Delta T_{1 / 2,2}$ を定める. それぞれ の吸収の $\Delta H_{a},(\tan \delta)_{\max }$, 之 $\Delta T_{1 / 2}$ と加ら2.2の場合 と同様汪，(4)，(7) ( (9)式加 $f_{e}$ と $n_{t}$ とを算出 する.

\section{3. 実 験}

\section{1 試料調製}

既報 ${ }^{9}$ で用いた $\mathrm{N} 66$ (末端 $\mathrm{NH}_{2}$ 基: $52 \mathrm{meq} / \mathrm{kg}$ ，末 端 $\mathrm{COOH}$ 基 : $70 \mathrm{meq} / \mathrm{kg}$, 粘度平均分子量 $M_{v}: 1.8 \times$ 104) 未分別物を原試料とした。乙のN66のチップを既 報9) と同様に加圧溶融成型して厚さ約 $250 \mu \mathrm{m}$ のフィルム

（未処理フィルム）を得た.フィルム面に平行および垂 直にX線を入射して得られた回折写真および偏光顕微鏡 観察より,フィルム内部の分子鎖はほとんど無配向状態 にあることを確認した. 未処理フィルムを自家製の延伸 器 ${ }^{10)}$ を用いて温度 $100 \sim 180^{\circ} \mathrm{C}$, 延伸倍数 $2.2 \sim 2.8$ 倍, 延伸速度 $200 \% / \mathrm{min}$ で热水中および綿実油中で延伸し た.'油中での延伸後, フィルム表面の油をアセトンで除 去した. 得られた延伸フィルムに付着した水およびアセ

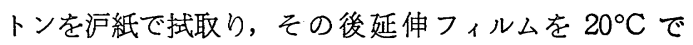
$48 \mathrm{hr}$ 以上真空 $\left(1 \times 10^{-2} \mathrm{mmHg}\right)$ 乾燥した.

また上記のN66チップを用い著者ら ${ }^{11}$ が陚作した小型 溶融紡条機を利用して, 紡口温度 $265^{\circ} \mathrm{C}$ で巻取温度 20 ${ }^{\circ} \mathrm{C}$, 吐出線速度 $50 \mathrm{~m} / \mathrm{min}$, 巻取線速度 $60 \mathrm{~m} / \mathrm{min}$ の条

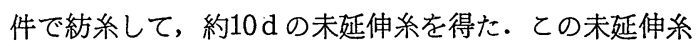

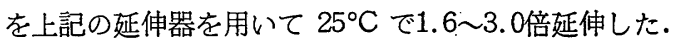




\section{2 热処理}

\section{A. 湿熱処理}

末処理フィルムをステンレス製オートクレーブ（内容 樻 $200 \mathrm{ml}$ ) 中で水ととも $2 \mathrm{~min}$ 以内で所定の熱処理 温度 $T_{a}\left(40 \sim 140^{\circ} \mathrm{C}\right)$ 飞加熱する (自由端). 所定時間 $t_{a}(5 \sim 120 \mathrm{~min})$ 熱処理後, $20^{\circ} \mathrm{C}$ の水中に投入して急冷 後の試料を $20^{\circ} \mathrm{C}$ で $48 \mathrm{hr}$ 以上真空 $\left(1 \times 10^{-2} \mathrm{~mm} \mathrm{Hg}\right)$ 乾燥した.

\section{B. 乾熱処理}

窒素ガス霩囲気中で 自由端で 所定温度 $\left(T_{a}=50 \sim 220\right.$ $\left.{ }^{\circ} \mathrm{C}\right)$, 所定時間 $\left(t_{a}=5 \sim 60 \mathrm{~min}\right)$ フィルムを熱処理した.

\section{3 測 定}

動的粘弾性温度特性を東洋ボールドウィン社製 Rheovibron DDV-II B およびII Cで測定した（測定周波数 $110 \mathrm{H}_{z}$, 昇温速度 $1^{\circ} \mathrm{C} / \mathrm{min}$, 穢維の場合は空気中, およ びフィルムの場合は乾燥空気中). 試料の 水分率の 調整 についての記載がない場合には，測定前に試料をあらか じめ $20^{\circ} \mathrm{C}, 60 \% \mathrm{RH}$ の雲囲気下に 1 週間以上静置して, 試料の水分率を調整した．精密天秤を利用して試料の乾 燥重量 $\left(150^{\circ} \mathrm{C} 30 \mathrm{~min}\right.$ 乾燥空気中で熱処理後直ちに重量 測定して得た值) $W_{0}$ と，水分収着後の試料重量 $W$ とを 測定し，乙れらを(10)式に代入して試料の水分率 $M(\%)$ を決定した。

$M=\left[\left(W-W_{0}\right) / W_{0}\right] \times 100$

結晶の大きさ $l$, 結晶配向度 $O A(\%)$ および結晶化度 を理学電機製X線回折装置 RU-200P/L で評価した. $l$ (Å) は Scherrer の式(11)式に (100) 面および (010), (110) 面の回折強度の半価幅 $\beta(\mathrm{rad})$ を代入して算出さ れた.

$$
l=\lambda / \beta \cdot \cos \theta \text {. }
$$

ことで, $\lambda$ は波長 (乙の場合, $1.543 \AA$ ) で $\theta$ は回折角で ある. $O A$ は (100) 面の回折強度の方位角方向の半価 幅 $H$ (度)を測定し，(12)式より定められた。

$O A=100(180-H) / 180$

結晶化度については, 䏶処理に伴う変動のみを, 赤道線 上の回折強度加ら定性的に評価した。

\section{4. 結果および考察}

\section{1 無配向フィルムの熱処理に伴う微細構造変化}

図 3 に $M$ を異にする無配向の未処理フィルムの $\tan \delta$ $-T$ 曲線を示す. 図中の数字は試料の $M(\%)$ である. $140^{\circ} \mathrm{C}$ 以上ではこれらの試料の $M$ は $0 \%$ ある. したが って $140^{\circ} \mathrm{C}$ 以上の温度でのてれらの試料の $\tan \delta$ の值 は $M=0 \%$ のとの值に等しい. 既報9で明らかにした ように $M=0 \%$ のきの温度 $120^{\circ} \mathrm{C}$ 亿位置する吸収（ $\alpha_{1}$ 吸収）は無定形領域内部の高分子主鎖のミクロブラゥン 運動に原因して発現する. $M=10 \%$ ときに $10^{\circ} \mathrm{C}$ に位

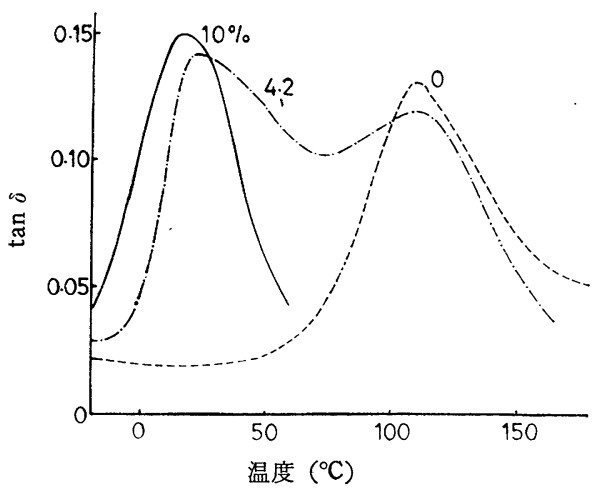

図 3 水分率 $(M)$ を異にする未処理フィルムの $\tan \delta-T$ 曲線 $(110 \mathrm{~Hz}):$

図中の数字は試料の水分率 $M(\%)$

置する四収（ $\alpha_{2}$ 吸収）は水分子が収着した無定形領域 内部のミクロブラウン運動に原因して発現する.

$M=4.2 \%$ よき, $\alpha_{1}$ 之 $\alpha_{2}$ 吸収の両者が同時に観察 される. $M>5 \%$ になると $\alpha_{1}$ と $\alpha_{2}$ 吸収とは分離する ことなく 1 個の吸収として観察される。詳しくみると， $8 \%>M>5 \%$ 範囲では， $M$ の増大に伴い $T_{\max }$ は低 温側へ移動し, 最終的には $M=8 \%$ おいてある漸近值 $\left(10^{\circ} \mathrm{C}\right)$ に近づく.

試料が吸湿する際には，分子鎖の充填状態の疎な無定 形領域内部に水分子が 選択的に収着される. このため 飞, 絶乾試料 $(M=0 \%)$ 飞打りる $\alpha_{1}$ 吸収の $T_{\max }$ よ り毛低温側の $\tan \delta$ を与える成分の吸収は低温側へ移動 して $\alpha_{1}$ 吸収と分離した吸収となる。乙れが $M=4.2 \%$ 試料の $\alpha_{2}$ 吸収の発現の理由である ${ }^{9)}$.

$\alpha_{2}$ 吸収の $T_{\max }$ 押よび $(\tan \delta)_{\max }$ は $M$ に依存して変 動する. $\tan \delta-T$ 曲線の測定過程中に $M$ は減少する. し たがって， $\alpha_{2}$ 吸収の $\tan \delta-T$ 曲線を2.3の方法で解析 して得られる $f_{e}$ と $n_{t}$ の絶対値については，厳密にい えば，それらが持つ前述の物理的意味をそのまま反映し た值ではない. しかし，2.3の方法で採用される值 ( $(\tan$ $\left.\delta)_{\text {max }}, T_{\text {max }}, \Delta T_{1 / 2}\right)$ は, 主として $T_{\text {max }}$ より低温側の $\tan \delta-T$ 曲線加ら評価される.すなわちこれらの值は $M$ の変動の小さい温度域から評価される.したがって, 試 料間で認められる $f_{t}$ と $n_{t}$ の相対的な変動については， 前述の物理的意味をそのまま反映すると近似できる。

$\alpha_{1}$ 吸収については，測定過程中の $M$ 変動は無視で きる $(M \simeq 0)$. したがって, $f_{e}$ と $n_{t}$ の絶対值は前述の 物理的意味をそのまま反映する。

図4 亿 $T_{a}$ を異にする湿熱処理試料の $\tan \delta-T$ 曲線 を示す $\left(t_{a}=30 \mathrm{~min}\right)$. 図中の数字は $T_{a}\left({ }^{\circ} \mathrm{C}\right)$ である. なお， $20^{\circ} \mathrm{C}, 60 \% \mathrm{RH}$ におけるそれぞれの試料の平衡 水分率 $M$ (この $M$ の值は $\tan \delta-T$ 曲線の測定開始時の 


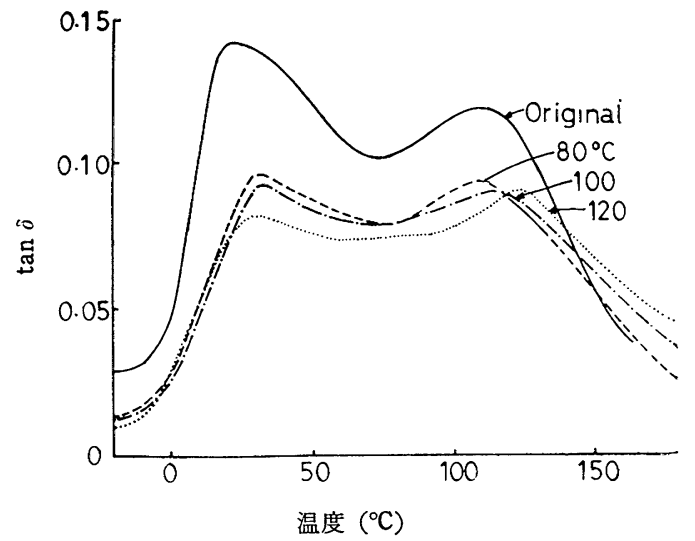

因 4 熱処理温度 $\left(T_{a}\right)$ を異にする湿熱処理試料の $\tan \delta-T$ 曲 線 $(110 \mathrm{~Hz})$ :

熱処理時間 $t_{a}$ は $30 \mathrm{~min}$

$M$ 亿等しい) は, 未処理フィルムでは $4.14 \%, T_{a}=80^{\circ} \mathrm{C}$ の試料では $4.06 \%, T_{a}=100^{\circ} \mathrm{C}$ の試料では $4.04 \%, T_{a}$ $=120^{\circ} \mathrm{C}$ の試料では $3.51 \%$ ある。. 図 4 から明らかなよ うに $T_{a}$ の上犁に伴って $\alpha_{1}$ 之 $\alpha_{2}$ 吸収の両者の（ $\tan$ $\delta)_{\max }$ は減少する. 未処理フィルム (実線) では, $\alpha_{2}$ 吸 収の $\tan \delta$ のピーク值 $(\tan \delta)_{\max , 2}$ は $\alpha_{1}$ 吸収のそれ $(\tan \delta)_{\mathrm{mxx}, 1}$ より㿝大きく, $T_{a}=120^{\circ} \mathrm{C}$ の試料（点線） では逆に $\alpha_{1}$ 吸収の方が大きい，両者の $M$ の差は $0.63 \%$ にすぎない，すなわち両者の $\tan \delta-T$ 曲線の差は単な るMの差では説明できない，むしろ，微細構造の差に原 因する. $T_{a}=120^{\circ}$ の湿热処理物では $\alpha_{1}$ 吸仪は高温側 へ約 $15^{\circ} \mathrm{C}$ 移動し， $\alpha_{1}$ と $\alpha_{2}$ の両吸収は熱处理前にく らべてより明瞭に分離する。

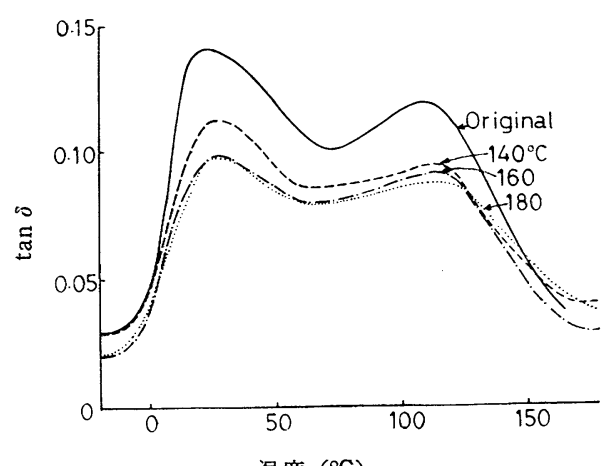

図 $5 T_{a}$ を異にする乾熱処理試料の $\tan \delta-T$ 曲線 $(110 \mathrm{~Hz})$ : $t_{a}=30 \mathrm{~min}$

図5に $T_{a}$ を異にする乾熱処理試料の $\tan \delta-T$ 曲線 を示す $\left(t_{a}=30 \mathrm{~min}\right)$. 図中の数字は $T_{a}\left({ }^{\circ} \mathrm{C}\right)$ である.な お，未処理フィルム， $T_{a}=140^{\circ} \mathrm{C}, 160^{\circ} \mathrm{C}, 180^{\circ} \mathrm{C}$ 热処 理試料の $20^{\circ} \mathrm{C}, 60 \% \mathrm{RH}$ におけるMはそれぞれ $4.14 \%$, $3.40 \% ， 3.27 \% ， 3.52 \%$ ある. $T_{a}$ の上昇に伴い（tan $\delta)_{\max , 1}$ は減少し, $(\tan \delta)_{\max , 2}$ は $T_{a} \leqq 160^{\circ} \mathrm{C}$ では減
少するが, $T_{a}>160^{\circ} \mathrm{C}$ では $T_{a}$ 亿依存しない. $T_{a} \leqq 180^{\circ} \mathrm{C}$ の乾熱処理では常に $(\tan \delta)_{\max , 2}>(\tan \delta)_{\max , 1}$ である.

図 4，5 および類似の $\tan \delta-T$ 曲線を図 2 のように 分割し，2.3で示した方法を利用して $f_{\theta}, n_{t}$ を炔定し た. ただしての際 $\alpha_{1} ， \alpha_{2}$ 吸収の $\Delta H_{a}$ としてはそれぞ れ55および $42 \mathrm{kcal} / \mathrm{mol}^{91}$ を採用した．厳密には $\Delta H_{\text {。 }}$ は $M$ 依存するが，ここでは $M$ 依存性を無視した.

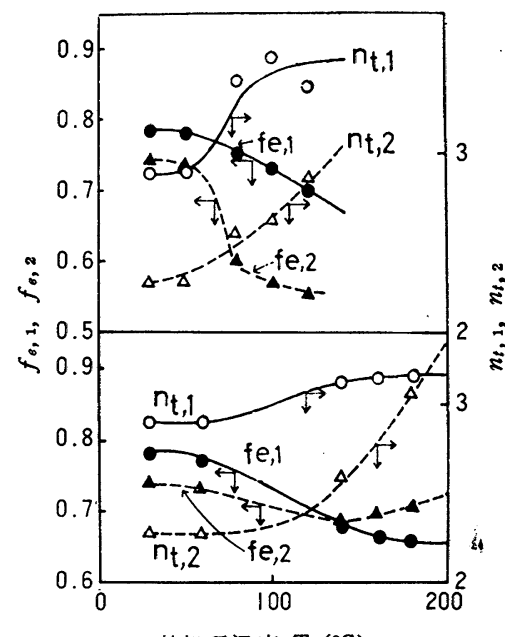

図 6 弾性率分率 $\left(f_{e}\right)$, 不均一度指数 $\left(n_{t}\right)$ の $T_{a}$ 依存性 $\left(t_{a}=\right.$ $30 \mathrm{~min})$ :

上図は湿熱処理, 下図は乾熱処理の結果を示す.黒丸； $\alpha \mathbf{1}$ 吸 収の $f_{e}\left(\equiv f_{e}, 1\right)$, 白丸; $\alpha_{1}$ 吸収の $n_{t}\left(\equiv n_{t}, 1\right)$, 黒 3 角; $\alpha_{2}$ 吸収の $f_{e}\left(\equiv f_{e}, 2\right)$, 白 3 角; $\alpha 2$ 吸収の $n_{t}\left(\equiv n_{t}, 2\right)$

図6に $f_{e}, n_{t}$ の $T_{a}$ 依存性を示す $\left(t_{a}=30 \mathrm{~min}\right)$. 上 図は湿熱処理を下図は乾熱処理を示す。果丸と白丸はそ れぞれ $\alpha_{1}$ 吸収の $f_{e}\left(f_{e}, 1\right)$ および $n_{t}\left(n_{t}, 1\right)$ を, 黒 3 角之白 3 角之はそ机ぞれ $\alpha$ 吸収の $f_{e}\left(f_{e}, 2\right)$ および $n_{t}$ $\left(n_{t}, 2\right)$ を意味する. 湿熱および乾熱処理のいずれの場 合す $T_{a}$ が上昇すると $n_{t, 1}$ と $n_{t, 2}$ とは增大し， $f_{e, 1}$ および $f_{e}, 2$ は減少する. いいかえると，熱処理温度が 高いほど無定形領域の不均一度は增し，乙の領域の弾性 率分率は低下する．特に $n_{t, 2}$ の $T_{a}$ 依存性は大きい. 湿熱処理に伴う $f_{0,2}$ の減少量は $f_{0,1}$ のそれよりあ大き いが, 乾熱処理では逆に $f_{b, 1}$ の減少量が大きい.

図7 亿 $f_{e}, n_{t}$ の $t_{a}$ 依存性を示す. 図7 (a) は湿熱 $100^{\circ} \mathrm{C}$ 処理, 図7(b)は乾熱 $180^{\circ} \mathrm{C}$ 処理についての結 果である. 黒丸と白丸とはそれぞれ $f_{e, 1}$ および $n_{t, 1}$ を， 黒 3 角之白 3 角とはそれぞれ $f_{e}, 2$ および $n_{t}, 2$ を意味す る. 図 7 加ら明らかなように, $f_{e, 1}, f_{e}, 2, n_{t, 1}, n_{t, 2}$ は 熱処理の初期において著しく变動する．すなわち， $n_{t}$ は 湿熱処理によって急激に増加し，以後は徐々に減少する。 乾熱処理の場合には $n_{t}$ は徐々に増加する. $f_{e}$ は熱処理 時間の経過ととあに減少する. 


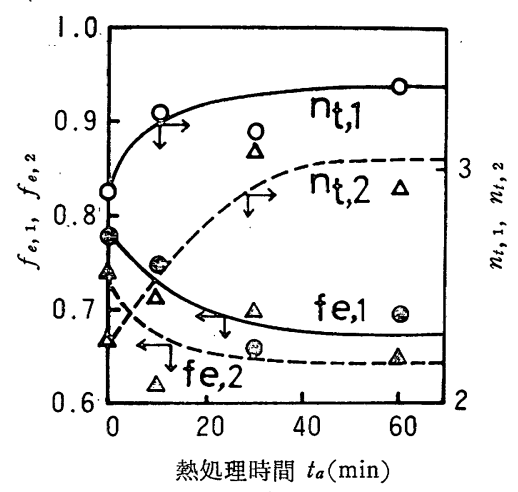

(a)

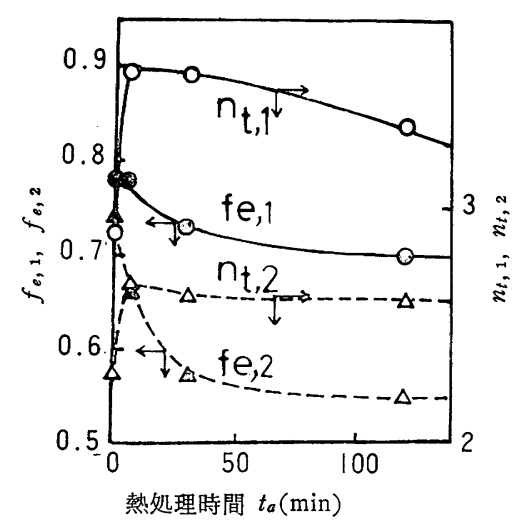

(b)

図 $7 f_{e}, n_{t}$ の $t_{a}$ 依存性:

（a）：湿熱 $100^{\circ} \mathrm{C}$ 処理，(b)；乾熱 $180^{\circ} \mathrm{C}$ 処理

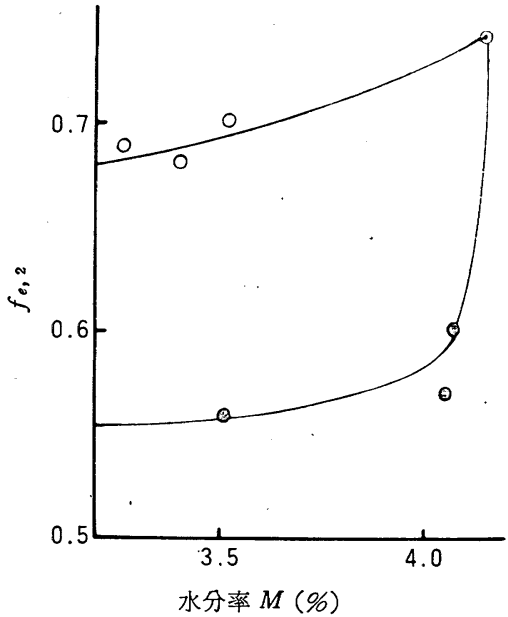

因 $8 f_{e, 2}$ の水分率 $M$ 依存性 :

$M$ は $20^{\circ} \mathrm{C}, 60 \% \mathrm{RH}$ に扔ける平衡水分率, 黒丸は湿熱処理, 白丸汁乾熱処理, 2 重丸は末処理フィルム

図8に $t_{a}=30 \mathrm{~min}$ で $T_{a}$ を変化させて得た愁処理試 料の $f_{e, 2}$ を $20^{\circ} \mathrm{C}, 60 \% \mathrm{RH}$ に沶ける試料の水分率 $M$ に 対してプロットした. 黒丸は湿熱処理, 白丸は乾熱処理 で得られた試料の值を, 2 重丸は未処理試料の值を示 す. 湿熱抢よび乾熱処理試料でMの大きい試料では $f_{e}, 2$ あ大きい. 同一のMの值で比較すると, 乾熱処理試料の $f_{e}, 2$ の方が湿热処理試料のそれよりも大きい. 弾性分率 $f_{e}$ は，その定義より注目する吸収（図8では $\alpha_{2}$ 吸収） に寄与する弾性率の全弾性率 (この場合は $\alpha_{1}, \alpha_{2}$ 吸収 と，例えば結晶吸収のように $\alpha_{1}$ 吸収より高測倒に位置 する吸収之に寄与する弾性率の和）に占分分率に等し い. したがって, 同一の $M$ で両热処理試料の $f_{e}, 2$ を比 較したときに認められる大きな差から，乾熱処理試料で は湿熱処理試料にくらへて，（1） $\alpha_{2}$ 吸収に寄与する領 域（領域II）量（すなわち水分か収着した無定形領域量） が大きいか, (2)単位領域量当りの $\alpha_{2}$ 吸収へ寄与する
弾性率が大きいか，（3） $\alpha_{1}$ 吸収およびそれより高温の 吸収に寄与する弾性率が小さいか，の場合が推察され る.

上述の湿熱と乾熱処理との差をさらに明らかにするた めに，湿熱と乾熱処理とを繰返へし与えた場合の $\tan \delta$ $-T$ 曲線の変化を検討した. 図 9 (a)k $T_{a}=120^{\circ} \mathrm{C}, t_{a}$ $=30 \mathrm{~min}$ の湿熱処理試料 $\left(20^{\circ} \mathrm{C}, 60 \% \mathrm{RH} \rho M=1.39\right.$ $\%$, 黒丸）と，乙の試料をさらに $200^{\circ} \mathrm{C} 5 \mathrm{~min}$ 乾熱処 理した試料（ $M=0 \%$, 白丸) との $\tan \delta-T$ 曲線を示 す. 図9(b)には $T_{a}=180^{\circ} \mathrm{C}, t_{a}=30 \mathrm{~min}$ 乾熱処理試 料 $\left(M=1.11 \%\right.$, 褁丸) と, 乙の試料をさらに $200^{\circ} \mathrm{C}$, $5 \mathrm{~min}$ 乾熱処理した試料 $(M=0 \%$, 白丸) と, 白丸の 試料を $100^{\circ} \mathrm{C}, 10 \mathrm{~min}$ 湿熱処理した試料 $(M=1.0 \%$, 黒 3 角) の $\tan \delta-T$ 曲線を示す. 図 9 (a)加ら明らか なように，湿熱処理試料では $91^{\circ} \mathrm{C}$ と $120^{\circ} \mathrm{C}\left(\boldsymbol{\alpha}_{1}\right.$ 吸収 $)$ とに 2 個の吸収が存在するが, 乾熱処理試料では $91^{\circ} \mathrm{C}$ の吸収のみが顕著に観察される. 逆に, 図 $9($ b $)$ に示す ように湿热処理によって $\alpha_{1}$ 吸収が影著に出現する. $91^{\circ} \mathrm{C}$ 亿位置する吸収に関する報告例はない。しかし図 9 (a)，(b)加ら明らかなように $M=0 \%$ の乾熱処理試 料には $91^{\circ} \mathrm{C}$ の吸収が明瞭に認められる(特に図 $9(\mathrm{a})$ の白丸). $M=0 \%$ のきの $\alpha_{1}$ 吸収の $T_{\max }$ は約 $120^{\circ} \mathrm{C}$ である. $\alpha_{1}$ 吸収と乙の吸収の $T_{\max }$ との差は約 $30^{\circ} \mathrm{C}$ あある. それ故, $T_{\max }=91^{\circ} \mathrm{C}$ の吸收は $\alpha_{1}$ 吸収打よび $M \neq 0$ のときにのみ現われる $\alpha_{2}$ 吸収のいずれにあ同定 できない，そこでての吸収を仮りに $\alpha_{2^{\prime}}{ }^{\prime}$ 吸収之名付け る.

今 $\alpha_{1}$ 吸収を与える領域を領域 I,$\alpha_{2}^{\prime}$ 吸収を与える 領域を領域II'亡すると図9(a)，(b)飞認められる $\alpha_{1}, \alpha_{2}^{\prime}$ 吸収の $(\tan \delta)_{\max }$ の熱処理に伴う変動は以下 のように言い換えることができる.すなわち， $T_{a}=$ $200^{\circ} \mathrm{C}$ の乾熱処理により領域Ｉは減少し領域II'が出現 


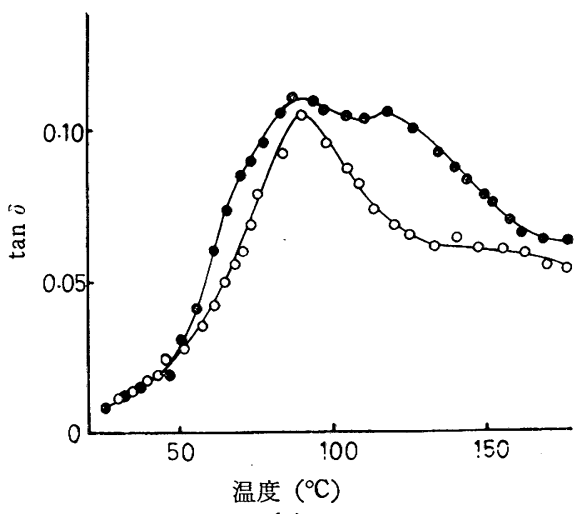

(a)

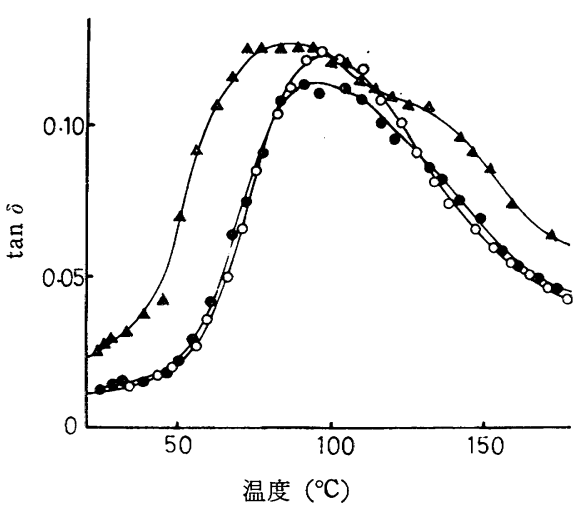

(b)

図 9 湿熱と乾熱処理を繰返し与えた試料の $\tan \delta-T$ 曲線 $(110 \mathrm{~Hz})$ :

(a); 黒丸は $T_{a}=120^{\circ} \mathrm{C}, t_{a}=30 \mathrm{~min}$ の湿熱処理試料 $\left(20^{\circ} \mathrm{C}, 60 \% \mathrm{RH}\right.$ の条件下で 1 日放置したときの $\left.M=1.39 \%\right)$, 白丸 は黒丸の試料を $200^{\circ} \mathrm{C}, 5 \mathrm{~min}$ 乾熱処理後 $20^{\circ} \mathrm{C}$ に急冷した試料 $\left(20^{\circ} \mathrm{C}, 0 \% \mathrm{RH}\right.$ に 1 時間放置したときの $\left.M=0 \%\right)$ ，(b)； 黒丸は $T_{a}=180^{\circ} \mathrm{C}, t_{a}=30 \mathrm{~min}$ 乾熱処理料 $\left(20^{\circ} \mathrm{C}, 60 \% \mathrm{RH}\right.$ の条件下で 1 日放置したときの $\left.M=1.11 \%\right)$, 白丸は黒丸の試料 を $200^{\circ} \mathrm{C} 5 \mathrm{~min}$ 乾熱処理後 $20^{\circ} \mathrm{C}$ へ急冷した試料 $\left(12^{\circ} \mathrm{C}, 0 \% \mathrm{RH}\right.$ に $1 \mathrm{hr}$ 放置したときの $\left.M=0 \%\right)$ ，黒 3 角は白丸の試料を $100^{\circ} \mathrm{C}, 10 \mathrm{~min}$ 湿熱処理した試料（ $\left(20^{\circ} \mathrm{C}, 60 \% \mathrm{RH}\right.$ の条件下で 1 日放置したときの $\left.M=1.0 \%\right)$. ( ) 内の值は测定直前の $M$ の 值である

する.湿熱処理では領域II に比べて領域I が相対的に 大きくなる．また前述の湿热と乾熱処理試料の $f_{e, 2}$ の 差は, 領域 I と領域 $\Pi^{\prime}$ とへ同一量の水分が収着した場 合, 領域Iから領域Iへの転移に比べて領域I' から領 域Iへの転移の方が，量的にはより多いために生じたあ のと解勫できる.乙の解釈は前述の（1）の場合に対応 する.

\section{2 延伸飞伴う微細構造変化}

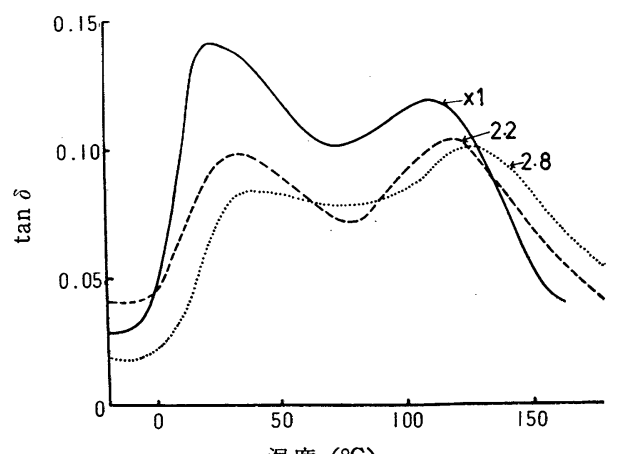

四10未処理 (無配向) フィルム拈よび延伸フィルムの $\tan$ $\delta-T$ 曲線 $(110 \mathrm{~Hz}):$

図中の数字は延伸倍率(倍), 延伸条件 ; $180^{\circ} \mathrm{C}$ 綿実油中で延 伸速度 $200 \% / \mathrm{min}$

未処理フィルム（図 4 参照）を $180^{\circ} \mathrm{C}$ の綿実油中で 延伸速度 $200 \% / \mathrm{min}$ で2.2お よび2.8倍まで延伸した。

これらの延伸フィルムの $\tan \delta-T$ 曲線を未処理フィル ムのそれととあに図10に示す。なお， $\tan -T$ 曲線の測 定の際，正弦ひずみは試料の延伸方向之同一方向に与え られた。図中の数字は延伸倍率である. $20^{\circ} \mathrm{C} 60 \% \mathrm{RH}$ のときの $M$ の值は未処理フィルムでは $4.14 \%, 2.2$ 倍延
伸試料では $3.68 \% ， 2.8$ 倍延伸試料では 3.30\%である. 延伸倍率の増大に伴なって, $\alpha_{1}$ 吸收の $(\tan \delta)_{\max }$ はわ ずかに減少し, その温度位置 $T_{\max }$ は高温側へ移動す る. $\boldsymbol{\alpha}_{2}$ 吸収の $(\tan \boldsymbol{\delta})_{\max }$ は延伸倍率が大きくなると $\alpha_{1}$ 吸収に比較してょり顕著に減少し，その $T_{\max }$ は高 温側へ移動する。一方, (100) 面の回折より定めた結晶 の大きさは，未処理フィルムでは $21 \mathrm{~A} ， 2.8$ 倍延伸試料 では59Aへ，その結晶の配向度は85.8\%へ，それぞれ延

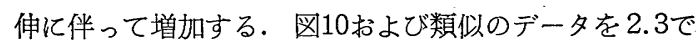
示した方法で解析した結果を図11亿示す. 四中里丸，白

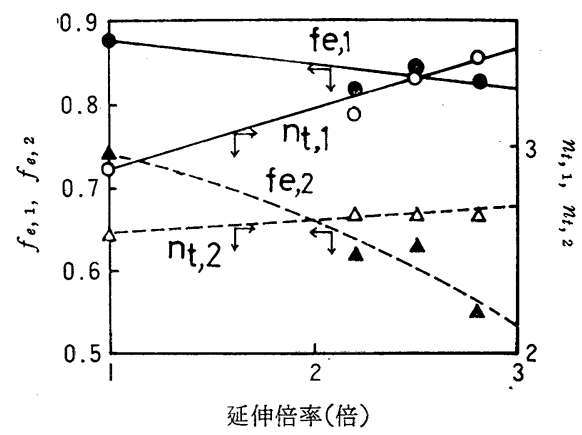

図11 $f_{e}, n_{t}$ の延伸倍率依存性:

黒丸; $f e, 1$, 白丸; $n_{t}, 1$, 黒 3 角; $f_{e, 2}$, 白 3 角; $n_{t, 2}$

丸はそれぞれ $f_{e, 1}$ および $n_{t, 1}$ を，黒 3 角および白 3 角はそれぞれ $f_{e}, 2$ および $n_{t}, 2$ を意味する. 延伸倍率 が增大すると $f_{e}, 1$ と $f_{e}, 2$ は (特に $\left.f_{e}, 2\right)$ 減少し, $n_{t, 1}$ 之 $n_{t, 2}$ (特に $\left.n_{t, 1}\right)$ は増加する.すなわち, 延伸に伴 って無定形領域内部の分子鎖の充填状態はより密にな り, その結果その充填状態の不均一さは增加する. 充填 状態の疎密が水素結合の疎密に対応するならば分子鎖の 
配向に伴って分子間水素結合の密度が特に大きな方向へ 幅広く分布すると推察される。

延伸温度の影響は, 後述の延伸試料の熱処理の際の $T_{a}$ の影響の場合之定性的には一致する. 例えば延伸温 度が高くなると, 結晶の大きさ $l$ が増加し, 配向度 $O A$ が減少し, $f_{e, 1}, f_{e}, 2, n_{t, 1}, n_{t, 2}$ は $140 \sim 160^{\circ} \mathrm{C}$ の延伸 温度で最小值をとる. これらの結果は延伸試料の熱処理 の際の $T_{a}$ 依存性と一致する. 延伸媒体に水を採用した 場合には，延伸温度の微細構造に及ばす影響は，その温 度より $80 \sim 140^{\circ} \mathrm{C}$ 高温の綿実油中での延伸温度のそれに ほぼ対応する。

4.3 延伸後熱処理に伴う微細構造変化

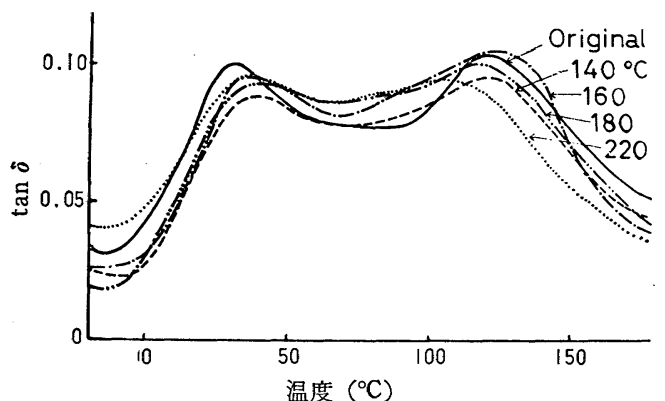

因12延伸フィルムを種々の温度で熱処理した際の $\tan \delta-T$ 曲 線 $(110 \mathrm{~Hz})$ :

Original； $180^{\circ} \mathrm{C}$ の綿実油中で延伸速度 $200 \% / \mathrm{min} て ゙ 2.5$ 倍 延伸して得られた熱処理前の試料, 四中の数字は $T_{a}\left({ }^{\circ} \mathrm{C}\right)$, $t_{a}=30 \mathrm{~min}$

図12に $180^{\circ} \mathrm{C}$ の綿実油中で2.5倍延伸して得られた延 伸フィルムを自由端で $T a=140 \sim 220^{\circ} \mathrm{C}, t_{a}=30 \mathrm{~min}$ 乾熱処理したときの $\tan \delta-T$ 曲線を示す. 図中の数字 は $T_{a}\left({ }^{\circ} \mathrm{C}\right)$ を意味する. $T_{a}$ が上昇すると， $\alpha_{1}$ と $\alpha_{2}$ 吸

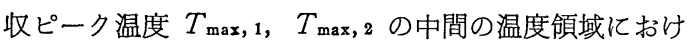
る $\tan \delta$ 值が増加する. $T_{a}=220^{\circ} \mathrm{C}$ のとき, $T_{\max , 1}$ と $T_{\max , 2}$ の両者が相互に接近する. 自由端で $T_{a}=80$ 〜 $140^{\circ} \mathrm{C}$ の湿熱処理では，乙のような両吸収の接近は認め

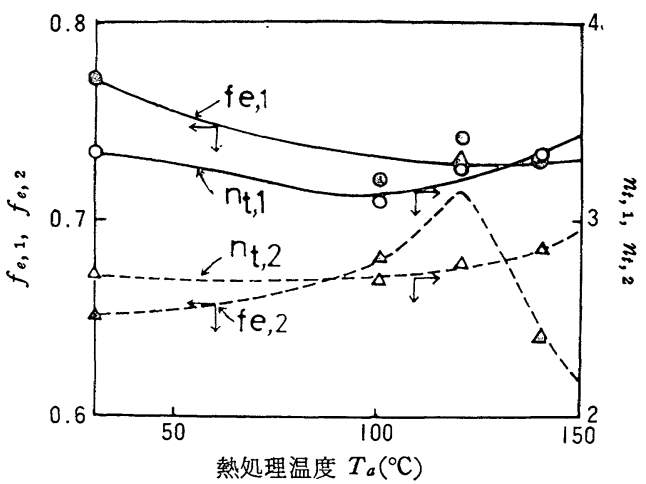

(a)
られない (データ省略).

図12および湿熱処理で得た $\tan \delta-T$ 曲線を2.3の方法 で解析して $f_{e}, n_{t}$ を决定した. 図13に延伸フィルムを 湿熱 $(\mathrm{a})$, 乾熱 $(\mathrm{b})$ 処理したときの $f_{e}, n_{t}$ の $T_{a}$ 依存 性を示す (自由端, $t_{a}=30 \mathrm{~min}$ ). 黒丸および白丸はそ れぞれ $f_{t, 1}, n_{t, 1}$ を, 果 3 角之白 3 角はそれぞれ $f_{e, 2}$, $n_{t, 2}$ を示す. 延伸フィルムを熱処理すると無配向フィ ルムの場合 (図6 参照) と異なり, (1) 乾熱処理では $T_{a}=160^{\circ} \mathrm{C}$ で $f_{e}, n_{t}$ 亿極小值を示す乾熱処理の $T_{a}$ は ほぼ綿実油中での延伸温度に近い，また(2)湿熱処理で は $T_{a}=120^{\circ} \mathrm{C}$ で $f_{e}, 2$ のみ極大值を示し, $n_{t}$ は $T_{a}$ と とあに単調に增加する。一方, 延伸フィルムのX線解析 結果によると， $T a$ が上昇すると $l$ は単調に増大し, $O A$ は単調に減少し, 極大や極小值はない.すなわち熱 処理に伴って分子鎖の配向は乱れ，無配向フィルムの熱 処理の場合之同様に結晶は大きくなる．分子鎖の配向の 乱れが延伸倍率の減少に対応すると仮定すれば， $T_{a}$ の 上昇は延伸倍率の減少に対応し, 従って $T_{a}$ の上年に伴 って $f_{\theta}$ は增大し， $n_{t}$ は減少するはずである．無配向 試料の熱処理の場合には， $T_{a}$ が上昇すると $f_{e}$ は減少 し， $n_{t}$ は増加する (図6 参照)。すなわち延伸フィルム の熱処理の際には， $f_{e}, n_{t}$ に及活す影響が相互に異な る2 種の効果 (分子鎖の配向の乱れの効果之無配向試 料への愁処理効果) が同時に認められる. このために (1)，(2)のような極小值が現われるのであろう.

4.3 N66単繊維の微細構造の延伸倍率依存性 未延伸瀻維 $(10 \mathrm{~d})$ を空気中で, $25^{\circ} \mathrm{C}$, 延伸速度 200 \%/min の条件で1.6〜3.0倍延伸した. てのようにして 得た延伸繊維の $\tan \delta-T$, 動的弾性率 $E^{\prime}-T$, 損失弾 性率 $E^{\prime \prime}-T$ 曲線を図14亿示す，実線は未延伸瀻維，破 線は1.6倍, 1 点鎖線は2.0倍, 2 点鎖線は2.6倍, 点線 は3.0倍の延伸繊維を意味する．Mの延伸倍率依存性は 無視でき4.10〜3.90\%の範囲内で変動する．延伸倍率の

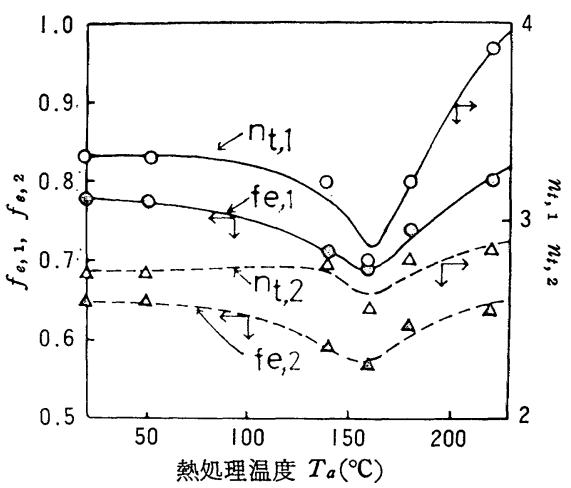

(b)

図13 延伸後熱処理フィルムの $f_{e}, n_{t}$ の $T_{a}$ 依存性(自由端, $t_{a}=30 \mathrm{~min}$ ): (a); 湿熱処理, (b); 乾熱処理, 黒丸; $f_{e, 1}$, 白丸; $n_{t, 1}$, 黒 3 角; $f_{t, 2}$, 白 3 角; $n_{t, 2}$ 


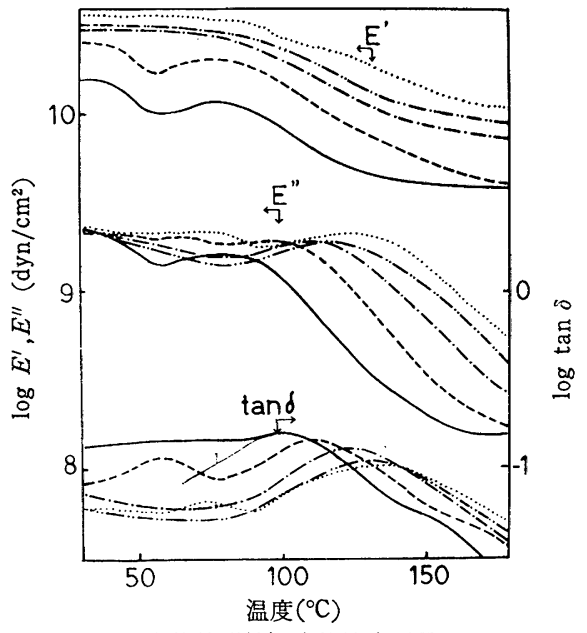

図14 延伸瀻維の動的粘弹性温度特性 $(110 \mathrm{~Hz}): E^{\prime}$; 動的弹性 率, $E^{\prime \prime}$; 損失弾性率, 実線は未延伸瀻維 (約 $\left.10 \mathrm{~d}\right)$, 破線は 1.6 倍， 1 点鎖線は2.0倍， 2 点鎖線は 2.6 倍，点線は 3.0 倍の 延伸瀻維，延伸条件； $25^{\circ} \mathrm{C}$ 空気中，延伸速度 $200 \% / \mathrm{min}$

增大に伴い $E^{\prime}$ は大きくなる．また $\tan \delta-T$ 曲線に おいて，延伸倍率が大きくなると， $\alpha_{2}$ 吸収は減少する， 一方このとき $(\tan \delta)_{\max , 1}$ は減少し, $T_{\max , 1}$ あ高温側 へ移動する．これらの結果はいずれも前述の延伸フィル 么の場合の延伸倍率依存性の結果と定性的には同一傾向 である.

図14の $\tan \delta-T$ 曲線では $\alpha_{2}$ 吸仪は $\alpha_{1}$ 吸収に比べ て小さい．未延伸瀻維の場合を除き $\alpha_{1}$ 吸収のみに対応 する $\tan \delta-T$ 曲線を実測の $\tan \delta-T$ 曲線加らほぼ完全 に分離できる，ただし未延伸絨維の場合には， $T_{\max }$ よ り低温側の $\tan \delta-T$ 曲線を, 2.0 倍延伸繊維の $\tan \delta-T$ 曲線と同じ形になるように描き，乙の曲線を $\alpha_{1}$ 吸収の $\tan \delta-T$ 曲線とした (図中細実線 1 参照)。乙のように して得た $\alpha_{1}$ 吸収の $\tan \delta-T$ 曲線を2.1の方法で解析 し $f_{e, 1}, n_{t}, 1, F(n)$ を定めた.

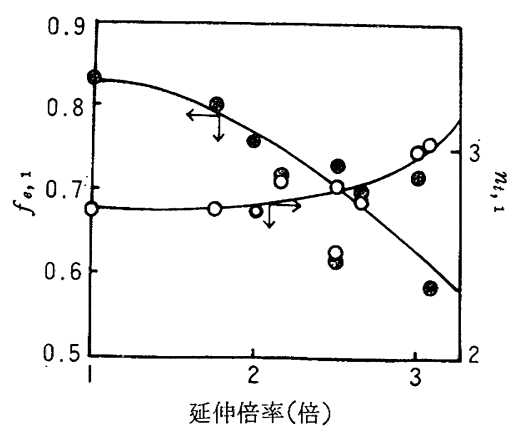

図15 延伸瀻維の $f_{e}, 1, n_{t, 1}$ の延伸倍率依存性 : 黒丸; $f_{e}, 1$, 白丸; $n_{i, 1}$

図15に図14およびそれと類似のデータを解析して得た $f_{e}, 1, n_{t, 1}$ の延伸倍率依存性を示す. 延伸倍率が大きく

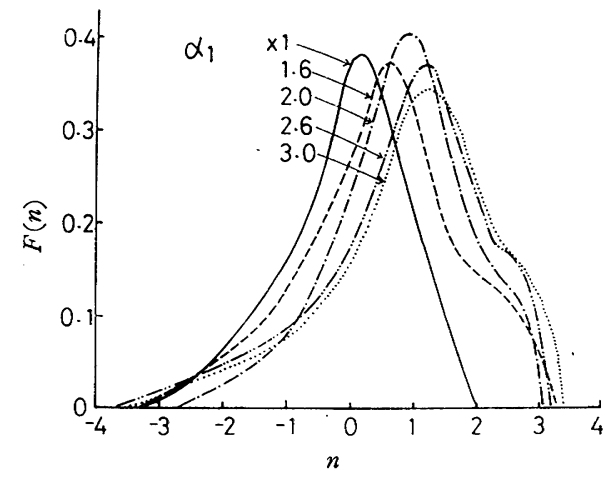

図16 $\alpha_{1}$ 吸収に関する延伸織維の充填度分布関数 $F(n)$ : 図中の数字は延伸倍率 (倍), 延伸瀻維の本文中 (1)式に招け る $T_{\max }$ 扔よび(6)式の $\Delta H_{a}$ として未延伸㵶維の值を採用 した.

なると $f_{e, 1}$ (黒丸) は減少し， $n_{t, 1}$ (白丸) は增加す る、この図の結果はややばらつきが多いが図11の延伸フ ィルムの結果と定性的には一致する。

図16に $\alpha_{1}$ 吸収に関する分子鎖の充填度分布関数 $F(n)$ を示す.ただし(1)式の $T_{\max }$ には未延伸瀻維の $T_{\max }$ を採用して $n$ を定めた. 図中の数字は延伸倍率で ある．との図より延伸倍率の増大とともに分子鎖の充填 状態の密な部分が増していることがわかる、フィルムの 延伸の場合々類似して，延伸に伴って無定形領域内部の 分子鎖の充填状態はより密になり，その充填状態の不均 一さは増大する。

\section{4. 結 言}

N66 の仮撚加工前の原糸の無定形領域内部の分子鎖 の充填状態の不均一さはポリエステルおよびアクリル繊 維に比べて大きいＮ６6 のフィルムおよび単瀻維を採 用して，それらの無定形領域の微細構造の詳細を， tan $\delta-T$ 曲線に関する著者らの解析方法を適用して明らか にした.

その結果，他の織維素材高分子（例えばポリアクリロ ニトリル，ポリエステル，ポリプロピレン，ポリビニル アルコールなど）の場合之同様に，熱処理により無定形 領域の弾性率分率 $f_{\mathrm{e}}$ は減少し，分子鎖の充填状態の不 均一さを示す不均一度指数 $n_{t}$ は增加する. また延伸に 伴い $f_{e}$ は減少し， $n_{t}$ は増加する．延伸後の熱処理では (1)分子鎖の配向の乱れに伴う $f_{e}$ の增加之 $n_{t}$ の 減少 と, (2) 無配向フィルムの熱处理の際汇認められる $f_{0}$ の減少と $n_{t}$ の增加との両者が同時に起る．そのため熱 处理に伴う $f_{e}, n_{t}$ の変動は複雑である. 分子鎖の配向 が同一であれば，延伸フィルムと延伸緘維とは類似の微 細構造を持つ.さらに乾熱処理によって生じる無定形領 域の微細構造に特徽的な $\tan \delta$ の吸収が新たに約 $90^{\circ} \mathrm{C}$ 
$(110 \mathrm{~Hz})$ に生じることが明らかになった。

\section{引用文献}

1）真鍋征一, 上出健二, 中山啺三; 䄉機誌, 30, T45 (1977)

2）真鍋征一, 上出健二, 中山暢三; 織機誌, 30, T55 (1977)

3）真鍋征一, 上出健二, 中山暢三; 綫機誌, 30, T66 (1977)

4) 真鍋征一, 上出健二, 中山暢三, 小林茂子; 織機誌, 30 , T85 (1977)

5）中山啺三, 上出健二, 真鍋征一; 坂本富男; 繊学誌, 33,
T-147 (1977)

6) 中山啺三, 上出健二, 真鍋征一; 織学誌 $33, T-192$ (1977)

7）中山暢三，上出健二，真鍋征一，坂本富男；緎学誌，33, $\mathrm{T}-199$ (1977)

8）真鍋征一, 上出健二, 中山啺三; 織機誌, 27, P 555 (1974)

9）中山暢三，上出健二，真銅征一，原正勝；緎学誌， 33 , $\mathrm{T}-281$ (1977)

10) 上出健二, 稲本義彦, 藤井清; 織学誌, 23, 86 (1967)

11) 上出健二, 稲本義彦; 緎学誌, 23, 79 (1967) 